\title{
Students' Perceptions in English Learning Using 3 Online Media Applications as a Learning Media in Pandemic Period
}

\author{
Nurfitri \\ STIA NUSA \\ email: fitrinur8833@gmail.com
}

\begin{abstract}
Since the increase of Indonesian people exposed to Covid-19 was massively reported, our government has tried to find best solution to overcome this situation, one of them is conducting online learning for the students. At STIA Nusa, English learning which was originally done offline, was changed to online with the obligation to use several online media applications such as Zoom, Edmodo and Whatssap. The purpose of this study was to look at the students' perception and ask the results of their English skills as well as offline learning. This research used qualitative, with data collection techniques are interviews with 128 students. The research results showed that 1). Zoom presents a new learning model even though most of them still say the lack of interaction, 2). The use of Edmodo for them is more interactive because they are able to repeat lessons and discuss with friends if there is a lack of understanding about learning and its user friendly features such as Facebook 3) the use of WhatsApp groups makes it easier for them to ask questions with the lecturer and through the voice note feature the lecturer can provide feedback what they need and through this application students can be rewarded so that it gives them the motivation to learn more during the pandemic.
\end{abstract}

Keywords: online learning, online media, covid-19 pandemic

\section{Introduction}

Since the increase of Indonesian people exposed to Covid-19 was massively reported, our goverment has tried to find best solution to overcome this situation. One of the solutions that Indonesian government has taken is in the form of policies for social distancing and physical distancing. During the implementation of social distancing and physical distancing policy, most activities outdoor and or involving a number of people were being limited until pandemic subsides. Social distancing and physical distancing policy were also applied to schools and colleges mostly by conducting online learning (school from home).

Online learning is a type of learning that uses an internet connection with means of accessibility, connectivity, and flexibility. Online learning could bring together students and lecturers to carry out learning interactions using the help of the internet (Kuntarto 2017). Then, online learning is a learning program carried out using a network to reach large and broad group of students (Bilfaqih, 2015). At its implementation, online learning requires the support of mobile devices i.e. smartphones, laptops, computers, tablets that it can be used to access learning materials anytime and anywhere (Gikas, J., \& Grant 2013). Universities during this work/school from home period are required to carry out online learning (Darmalaksana 2020).

The Nusantara Sakti School of Administrative Sciences (STIA Nusa) is one of the private universities located in Sungai Penuh city, Jambi province. Along with other universities in Sungai Penuh, it carries out online learning during the Covid-19 pandemic for almost two years already. One of the courses in STIA Nusa that already implemented a full online learning is Conversation course. 
Conversation classes were designed to be student centered where students become the key focus. Learning activities in conversation classes were used to carry out role playing collectively in front of the class, interactive topics discussions and dialogues practicing with peers, before the pandemic hits.

Under the pandemic situation, for sure there are some implementations of the course that need to be adapted into online learning style. Even though the stages of learning stay the same, STIA Nusa's lecturers need to be making use of several existing online applications such as Zoom cloud meetings, Edmodo, and WhatsApp groups. Zoom is one of the cloud computing-based video communication applications made by an American company. This application provides remote conferencing services by combining video conferencing, online meetings, chat, to mobile collaboration (Latifah 2020). Learning activities such as meeting $\&$ chat, video webinars, conference rooms, phone systems, and marketplaces are one of the advantages that make this application is widely used as a teaching and learning tool. Edmodo on the other hand, is a kind of educational social network that can be connected via on line service, platform, or web site that focuses on facilitating the constructing of social family members among human beings to proportion hobbies, sports, heritage or willing life connections. While WhatsApp is a messaging application for smartphones with a design similar to BlackBerry Messenger. WhatsApp Messenger is a cross-platform messaging application that allows us to exchange messages without SMS fees since it could be accessed without an extra charge or the need of special internet data plan; just the usual data plan we use to access e-mail, web browser, or social media.

The use of these three online learning applications in Conversation course is adjusted to students and lecturer's needs, according to certain situation and conditions. As an example, when the lecturer and students need more interaction, lecturers use Zoom cloud meeting application where materials could be explained by the lecturers and hopefully triggers discussions and dialogue interactions with the students. During the learning step where students are required to practice in class, lecturers create a conference room for groups of students to discuss what assignments were given and to be presented in the zoom cloud meeting next week. WhatsApp group and Edmodo applications were used to collect students' assignments, conduct class written discussions, repeat learning materials that have been posted, and more as a media to forego more discussion when learning process in Zoom was not understandable enough to students yet.

All these applications make it easier for students to learn from anywhere and for lecturers to keep interacting with their students. However, we may not know whether this application is able to build the same level of enthusiasm and understanding compared to offline learning activities. To answer this question, research is needed to derive from students' point of view or students' perception. Students who took Conversation class during the covid 19 pandemic became our respondents, we would like to address whether online learning using Zoom, Edmodo, and WhatsApp could build the same level of enthusiasm and understanding as learning offline. This research would as well address what were the problems/challenges faced by students during their online learning process with the use of three applications mentioned before.

\section{Methods}

This research used a qualitative approach. The purpose of this study is to describe students' perceptions during learning using three existing online learning media namely Zoom cloud meeting, Edmodo, and WhatsApp group. There were 128 students as research subjects whom had carried out online learning in our Conversation class during Covid 19 pandemic. Data collection is done through closed and open interviews via phone and or Zoom cloud meetings. Through the closed interviews, researchers interviewed students via Zoom cloud meeting with limited questions and provided answers in the form of choices. Meanwhile, open interviews were conducted after conducting closed interviews to obtain more data and validation. Data analysis was carried out using the analysis model of Miles \& 
Huberman (1994) which consisted of three stages, namely data reduction, data display, and conclusion drawing and verification.

\section{Result and Discussion}

The question asked during closed interviews were, "did you manage to understand the learning material well during online learning in the conversation class?" Results of closed interviews showed that 39 students admit if they did not understand the learning materials well enough during the online class, while 89 people said they could manage to somehow understand the online learning materials using the three existing media used in STIA Nusa. These results can be seen from the table below:

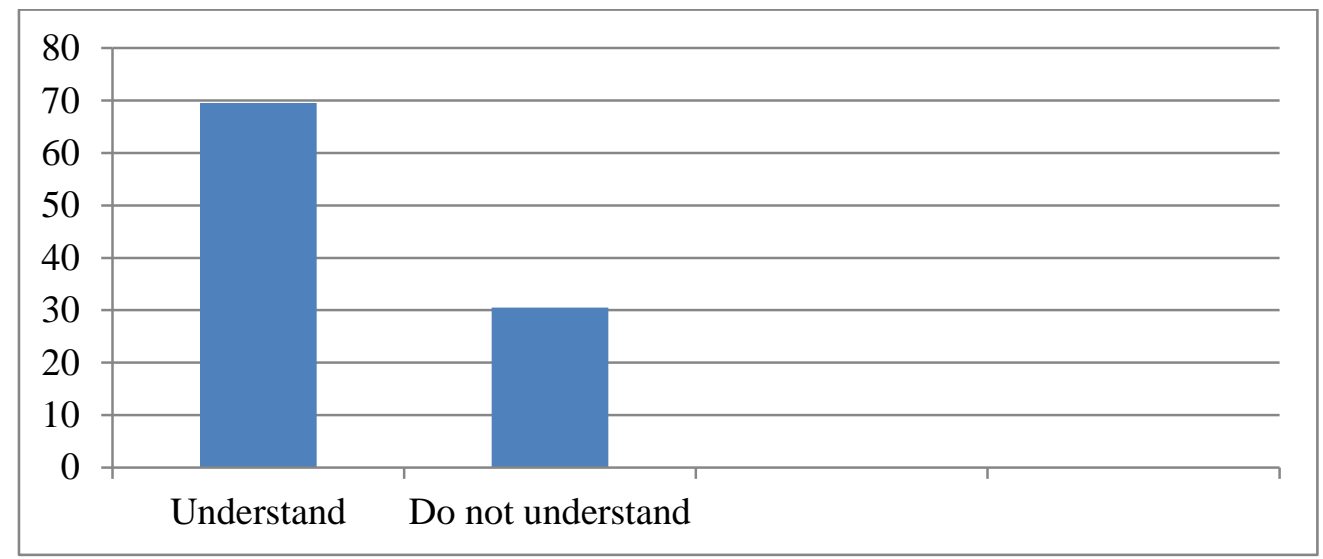

Figure 1. Percentage of students' Understanding in Online Learning

Moreover, from the open interview we've asked a question "what are the reasons that make you can't understand the materials during online learning?" Results showed that 39 students say if during the covid19 pandemic, most of them would only listen the materials without really think or write anything during the Zoom meeting. Thus, we may conclude that $31 \%$ of these students say they don't really understand learning well, even though the stages of learning have been carried out. According to them, there were problems such as connection problems, internet data/quota problems, and that they have problems listening to the explanation from the lecturer through unstable signals or unclear voices/noises distraction. In addition, most students do not take advantages of the time when lecturers ask and give feedbacks; they do not ask further questions even though they have difficulties in understanding the materials. As a result, the problem could not be resolved properly, and the use of online applications such as Edmodo and WhatsApp group were also not being used properly. Not to mention if their house were located in the suburbs far from a good connection of internet, this could affect their understanding as they need to search for stable internet connection which sometimes just a waste of time.

On the other hand, 89 students stated that they do understand the online learning materials. One of reason was because they were interested in the various uses of these online learning applications. So when the class began, they were more prepared with all learning needs/tools, such as they make notes and prepare themselves for face-to-face learning. They felt like Zoom meeting gave them a new spirit to meet and interact with each other, even if it was conducted online. They could understand the learning materials well because they beforehand have studied the lessons posted by lecturers on Edmodo, continuously ask questions in WhatsApp groups, as well as being actively involved in discussion during learning hours.

A follow-up question that we asked was: "from these 3 applications, which one do you think has helped you the most in understanding and learning the materials of our Conversation course?" This was the data obtained as a result of our follow-up question: 


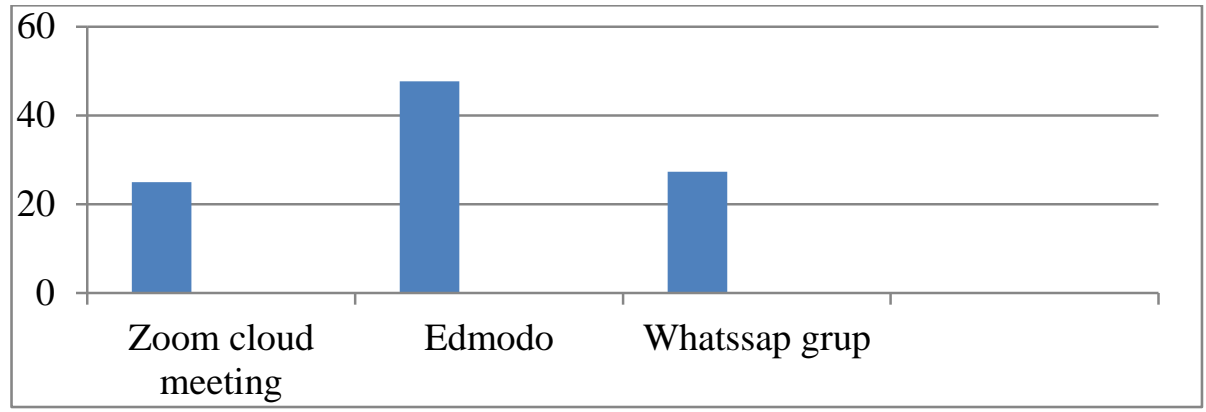

Figure 2. Percentage of students' choice on English Online Learning Media

From the table above, it can be seen that of the 128 interviewed students, 61 students choosing Edmodo at a percentage of $47.7 \%$. Furthermore, 35 students chose the Whatsapp group application at a percentage of $27.3 \%$, and lastly Zoom cloud meeting at only $25 \%$. Then an open interview was conducted to ask the reason why, of all $47.7 \%$ of students who answered Edmodo expressed their opinion that Edmodo was very helpful for them since they could find the materials, ask written questions, discuss and study the lesson there. When the lecturer sends the material, this is applied such as modules, teaching materials and other supporting materials such as videos that makes it easier for students to study at home and practice their conversations. Edmodo was also useful for class discussion as its feature is more or less looked like Facebook, making it easier for students to give comments or ask questions on the materials provided by the lecturer in the form of written tasks or voice recordings. Learning through Edmodo could be done anywhere and anytime, therefore the learning process did not just happen during class. That online platform was able to make it easier for students and teachers to interact with each other in an ongoing basis to flexibly discuss materials not only in the class but also outside the classroom (Yuniarti 2018). Results also shown that assignments in the form of videos were challenging for the students. $45 \%$ of the students stated that making videos increase their speaking skills during study and finishing the videos during given timeline has made them more discipline with time, as one of the features of Edmodo is enabling students to turn in their assignments within limited time given.

Most of the lectures, about $3 / 4$ of the total lectures in Conversation class, were taught by lecturers via Zoom cloud meeting application. According to students, the use of Zoom cloud meetings did not give them quite an interaction they need from the lecturers, most of the time they were only present to the Zoom meeting without giving much effort to take part in listening and reading lessons from lecturers' slides/materials. Despite some students may thought that Zoom cloud meetings could help lecturers explain the learning materials, somehow for materials that requires a more complicated explanation, the use of Zoom cloud meetings was not enough. Even though it is hoped to best replace the classroom interaction in face-to-face learning, students felt that face-to-face learning interactions could not be replaced by Zoom meetings due to its limited space for interaction between lecturers and students.

Students also thought that WhatsApp groups was capable to carry online learning, especially when their internet connection was limited and could no longer supports Zoom cloud meetings that took more internet data plan as it was using videos. In their opinions, the use of WhatsApp group was quite effective as it did not require that much internet quota. PDF and voice recording materials could also be saved into their phones and repeatedly accessed. That WhatsApp group provides many advantages, including: there was not a lot of wasteful quotas like other applications, materials presented by the teacher can be accessed by all students, and it was easier for students to have discussions about the material (Saragih and Ansi 2020) . The use of WhatsApp groups allows students and lecturers to interact directly using voice notes. Lecturers would initially explain learning materials through given the condition that interaction is limited so that no one could reply to chat or sent any comments in order to make sure that materials can be read completely and carefully. After that, lectures open the access to the chat room, enabling question and 
answer sessions. During this process, quite a lot of students would ask by giving comments and or sending voice notes. Questions will be answered by the lecturer via voice notes, as well as rewards such as emoji or expressions of justification would be given to make them eager to answer more and more questions. However, according to students, it will become ineffective when they have to wait in turn for their voice notes to be assessed by the lecturer. This would consequently take more time and sometimes the next lessons/materials have to wait as the lecturer needs to serve each and every question from students. Some students might miss the explanations for some questions during the day, thus making less and ineffective interactions. However, voice note explanations to other students' questions could provide new understanding for those who eager to learn but do not dare to ask/speak, so learning could still be repeated and understood.

Students were then asked about any problems they encounter during Conversation class using online learning applications. Almost all of the students mentioned that they would need more quota packages and a stable network to access Zoom cloud meeting. When lecturers asked to practice assignments, discussions and or presentations during the lessons, the learning process required a good and stable networks and control from the lecturer. Students would also need to listen and make some remarks on their notes, and this was quite difficult as some students might not mute their speakers during interactions, while lecturer forgot to unmute students; being busy explaining materials, not to mention noises from the unstable network might disturb the whole process. In science learning through Zoom Meeting application are inadequate facilities and infrastructure, disrupted internet connections, wasteful use of internet quotas and lecturers are not able to control and observe students one by one in full and cannot observe directly how students work in preparing and using their senses and materials when conducting experiments (Kelana, Wulandari, and Wardani 2021).

One critical problem found that when students were using Edmodo as a learning media was that they had difficulty sending assignments in the form of videos. It is with it was difficult for students to attach assignments with this application (Yuniarti 2018). When lecturers ask students to make assignments, students have to make video recordings then send them to Edmodo. Sometimes, size of the video must be taken into consideration, thus students might need to compress their videos before sending them; thus, requiring more effort and of course, more internet quota. On the other hand, most common problem we found when students learnt through WhatsApp groups was about time; voice notes from lecturers' explanations took time to download. Moreover, interacting while writing messages or voice notes often times made students confused and missed the explanations as the messages being stacked or their phone memories are full/limited.

\section{Conclusion}

Based on the results and discussions of this research, online learning applications play an important role during online learning in covid-19 pandemic. It is very appropriate to use media such as Zoom cloud meetings, Edmodo and WhatsApp groups since every student has different learning style, different passion and different interest in learning Conversation thus it would affect their understanding of the materials. From the research results we may conclude that some problems could still appear during the learning process using these three media, thus should be taken into account as reference to evaluate the success of online learning and could be used as a guide to improve the shortcomings in conducting the upcoming online learning.

\section{Acknowledgments}

The writer wants to say thanks for 128 students of second semester on STIA Nusa who gives their times to writer asking their opinions. The chief, lecturers and all of STIA-Nusa staffs who give the writer opportunity to do this research. 


\section{References}

Bilfaqih, Q. (2015). Esensi penyusunan materi pembelajaran daring, panduan berstandar penyusunan materi pembelajaran daring untuk pendidikan dan pelatihan. Yogyakarta: Deepublish.

Darmalaksana, W. (2020). WhatsApp kuliah mobile. Fakultas Ushuluddin UIN Sunan Gunung Djati Bandung.

Gikas, J., \& Grant, M. M. (2013). Mobile computing devices in higher education: student perspectives on learning with cellphones, smartphones \& social media. The Internet and Higher Education, 19, $18-26$.

Kelana, J. B., Wulandari, M. A., \& Wardani, D. S. (2021). Penggunaan aplikasi zoom meeting di masa pandemi covid-19. Jurnal Elementary, 4(1), 18-22.

Kuntarto, E. (2017). Keefektifan model pembelajaran daring dalam perkuliahan bahasa indonesia di perguruan tinggi. Journal Indonesian Language Education and Literature, 1(2), 207-20.

Latifah, L. (2020). Apa itu aplikasi zoom? alternatif rapat jarak jauh, begini cara kerjanya. etrieved from https://www.tribunnews.com/nasional/2020/03/18/apa-itu-aplikasi-zoom-alternatif-rapat-jarak-jauhbegini-cara-kerjanya

Saragih, E. M., \& Ansi, R. Y. (2020). Efektivitas penggunaan whatsapp group selama pandemi covid-19 bagi pelaku pendidik. Prosiding Seminar Nasional Multidisiplin Ilmu Universitas Asahan (September), 207-212.

Yuniarti, N. E. (2018). The effectiveness of edmodo as online learning platform to enhance students' english learning at X MIPA 6 In SMA Negeri 9 Semarang. Universitas Muhammadiyah Semarang. 